\title{
NIN Gene
}

National Cancer Institute

\section{Source}

National Cancer Institute. NIN Gene. NCI Thesaurus. Code C97668.

This gene is involved in the localization of the centrosome. 